\title{
THE UTILIZATION OF ELECTROMAGNETIC INDUCTION FOR HEATING THE THERMAL Agent in Closed Circuit Heating INSTALLATION
}

\author{
Blaga, V.; VlaD, I.; Vlad, M.; SOTOC, H.; \\ TIMAR, A. \& NAGHIU, O.
}

Abstract: Abstract: In this paper, we present the possibility of using electric energy for heating the thermal agent through electromagnetic induction in a metallic tube, placed into a closed circuit house heating installation. In order to obtain an electromagnetic field, we use an electronic generator with power tubes having the frequency of the alternative current grater than $10000 \mathrm{~Hz}$, which we used at the beginning for hard soldering of non-ferrous metal parts, realized by the University of Oradea, by Teodor Maghiar and Stefan Roman, for the vacuum tube technique of magnetron type. This high frequency generator, imbedded in the hydraulic circuit of the heating installation with sanitary water is non-polluting The novelty of the heating installation consists in the OLT35 tubes with a porous metallurgical coke core, which has the role of both pre-heater and thermal resistance.

Key words: electric energy, electromagnetic induction, high frequency generator, porous core, fluid thermal agent
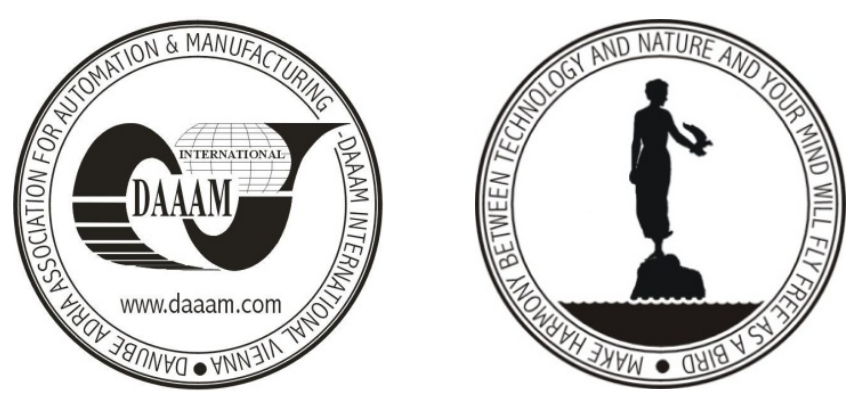

Authors' data: Dr., Prof. Blaga, V[asile]*; Prof. Vlad, I[oan]**; Asoc. Prof. Vlad, M[ariana]**; Lecturer Sotoc, H[oria ${ }^{* * *}$; Dr. Timar, A[drian] ${ }^{* * * *}$; Prof. Ass. Naghiu, O[vidiu $]^{* * * * *}$, *University of Oradea, Bumbacului street, nr.16, 3700, Oradea, RO, **University of Oradea, Romania, Bihor county, Oradea city, Dacia street, nr. 26, bloc D59,ap. 23, 410464, Oradea, RO, ***University of Oradea, Romania, Bihor county, Oradea city, street Calugareni, nr. 3, 410181, Oradea, RO, ****University of Oradea, Romania, Bihor county, Oradea city, Grigore Ureche street, 410485, Oradea, RO, *****University of Oradea, Romania, Bihor county, Oradea city, Nufarului street, nr. 27, D128 building,App. 31, 410533, Oradea, RO, atimar@gmail.com, branco_no@yahoo.com, ioanvlad2006@yahoo.com,_mariana_popvlad@yahoo.com, sotoc_horia@yahoo.com, vblaga_univ_oradea@yahoo.com

This Publication has to be referred as: Blaga, V[asile]; Vlad, I[oan]; Vlad, M[ariana]; Sotoc, H[oria]; Timar, A[drian] \& Naghiu, O[vidiu] (2008). The Utilization of Electromagnetic Induction for Heating the Thermal Agent in Closed Circuit Heating Installation, Chapter 06 in DAAAM International Scientific Book 2008, pp. 059-074, B. Katalinic (Ed.), Published by DAAAM International, ISBN 978-3-901509-66-7, ISSN 1726-9687, Vienna, Austria

DOI:10.2507/daaam.scibook.2008.06 